\title{
DIVERSIFIKASI PRODUK MINUMAN BERBAHAN BAKU RUMPUT LAUT: UPAYA PENINGKATAN EKONOMI SERTA PENGEMBANGAN PRODUK UNGGULAN UKM DI EKS-LOKALISASI DOLLY
}

\author{
Endang Purwanti ${ }^{1}$, Afifah Rosyidah ${ }^{1}{ }^{*}$, Irmina Kris Murwani $^{1}$ dan Ratna Ediati ${ }^{1}$ \\ ${ }^{1}$ Departemen Kimia, Institut Teknologi Sepuluh Nopember, \\ Kampus ITS Sukolilo-Surabaya 60111, Indonesia \\ *Email: afifah.chem@gmail.com
}

\begin{abstract}
ABSTRAK
Program pengabdian kepada masyarakat berbasis penelitian ITS yang dilakukan di daerah Ekslokalisasi Dolly Surabaya bertujuan untuk membantu meningkatkan pertumbuhan ekonomi masyarakat di wilayah tersebut. Rangkaian kegiatan penelitian ini meliputi pengujian kandungan gizi yang terdapat pada produk minuman sari rumput laut setelah dilakukan modifikasi penambahan beras merah. Komposisi yang diperoleh adalah Energi $=353 \mathrm{kkal}$; Protein = 7,4 gr; Lemak =0,7 gr; Karbohidrat = 76,1 gr; Kalsium = $13 \mathrm{mg} ;$ Fosfor = $359 \mathrm{mg}$; Zat Besi = 4,5 mg; Vitamin B1 = 0,35 mg; B6 0,4 mg;Vitamin E 0,2 mg; Vitamin K 1,3 $\mu$; Kalsium 19,6 mg; Zat Besi 0,9 mg; Magnesium 83,7 mg; Kalium 83,9 mg; Sodium 9,9 mg; Seng 1,3 mg; Tembaga 0,3 mg; Mangan 1,9 mg; Selenium 19,4 $\mu \mathrm{g}$.
\end{abstract}

Kata kunci: Pengabdian masyarakat ITS; Minuman Sari Rumput Laut; Analisa komposisi

\section{PENDAHULUAN}

Pada awalnya, daerah Dolly dan Jarak yang ada di Kelurahan Putat Jaya, Kecamatan Sawahan, Kota Surabaya, merupakan sebuah kawasan lokalisasi terbesar se-Asia Tenggara. Namun saat ini semuanya sudah berubah. Daerah Dolly dan Jarak terus menerus diupayakan untuk berubah menjadi lebih baik yakni Kampung Wisata sebagaimana dicanangkan oleh Walikota Surabaya, Tri Rismaharini, 21 Februari 2016 dengan berbagai produk andalan. Rencana Tri Rismaharini, didukung penuh melalui campur tangan anak muda Surabaya yang berdedikasi untuk memberdayakan warga eks-lokalisasi Dolly; yaitu para mahasiswa dan alumni perguruan tinggi di Surabaya yang tergabung dalam Gerakan Melukis Harapan (GMH) dan Surabaya Creative Network(Anggadiredja, J, 1996).

Semula hanya ada sekitar 13 warga yang memproduksi minuman rumput laut. Pembuatan minuman rumput laut ini dimulai setelah pelatihan yang diadakan Pemkot Surabaya dan mahasiswa. Sejak saat itu terus diproduksi rumput laut menjadi minuman olahan berbagai macam rasa: Leci, Strowberry, Lemon dan Green Tea. Tidak ada kesulitan untuk proses pembuatannya bahkan untuk rasa, komposisi serta sertifikasi HALAL dan BPPOM sudah didapatkan sertifikasinya; justru masalah pengemasan, diversifikasi produk olahan rumput laut dan Analisa Kecukupan Gizi menjadi kendala tersendiri.(Azrina, 2006)

Pelaksanaan kegiatan Pengabdian Kepada Masyarakat ini dimulai dengan serangkaian penelitian di laboratorium tentang diversifikasi, identifikasi dan analisis rumput laut saat masih fres maupun yang terkandung dalam minuman dan jelly yang sudah jadi, kemudian juga dilakukan analisis angka kecukupan gizi. 


\section{METODA}

\section{Alat}

Alat-alat yang dipergunakan pada kegiatan ini antara lain peralatan gelas: erlemeyer, beaker glass, gelas arloji, botol timbang, pipet tetes, pipet volum, neraca analitik, hotplate, waterbath, desikator, cawan porselen, oven, labu kjehdahl, tabung soxhlet, dan buret.

\section{Bahan}

Jenis rumput laut yang digunakan pada pembuatan minuman Orumy adalah Spinosum dan Cottonii, natrium hidroksida, asam klorida, BSA, aquabides, aquades, larutan buffer, larutan ninhidrin. Standard asam amino, asam sulfat, asam asetat, asam nitrat, asam metafosfat, asam perklorat, amonium molibdat, aminonaftol sulfonat, standard mineral ( $\mathrm{Ca}$, Fe dan P). Gas nitrogen, isopropanol, 2,6-diklorofenol indofenol, heksana, aseton, kloroform, boron trifluorida, kalsium karbonat, standard vitamin A dan C, natrium karbonat, metana, petrolium eter.(Kumalasari, 2010)

Analisis komposisi kimia dilakukan dengan mengacu pada metode standar yaitu penentuan kandungan air dengan cara dioven, penentuan protein kasar menggunakan metode Kjedhal, perhitungan lemak dengan Soxhlet, analisis abu dilakukan dengan metode pengabuan dalam oven, serta analisa karbohidrat dan serat kasar dengan metode gravimetrik.(Sulistyowaty D., 2009)

\section{Analisis mineral}

Preparasi sampel untuk analisis mineral $\mathrm{Na}, \mathrm{K}, \mathrm{Ca}, \mathrm{Mg}, \mathrm{Mn}, \mathrm{Zn}$, dan Fe dilakukan dengan prosedur pengabuan basah (AOAC 2005). Sampel rumput laut bahan minuman Orumy ditimbang $1 \mathrm{~g}$ dan

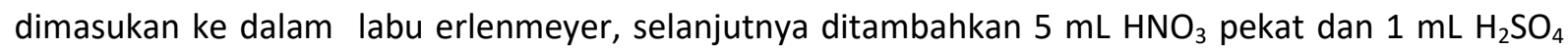
pekat lalu dibiarkan selama 1 malam, kemudian ditambahkan 2-3 tetes larutan campuran HCL dan $\mathrm{HNO}_{3}$ dengan perbandingan 2:1. Larutan dipanaskan pada suhu rendah sampai mengeluarkan gas berwarna coklat dan dilanjutkan dengan pemanasan pada suhu $150-200^{\circ} \mathrm{C}$ hingga larutan menjadi kuning muda jernih dan didinginkan hingga mencapai suhu ruang. Akuabides ditambahkan sedikit, disaring dengan kertas saring di dalam labu takar $100 \mathrm{~mL}$, kemudian bilas dengan akuabides sebanyak 2-3 kali. $\mathrm{HNO}_{3}$ pekat dan akuabides ditambahkan sebanyak $1 \mathrm{~mL}$ hingga mencapai $100 \mathrm{~mL}$, labu ditutup lalu aduk hingga homogen. Tahap pengukuran dengan Atomic Absorbtion Spectrofotometer (AAS): larutan standar dibuat dari masing-masing mineral dengan seri konsentrasi 0,$1 ; 0,2 ; 0,3 ; 0,4 ; 0,5 \mathrm{mg} / \mathrm{L}$ dan diukur absorbansi pada panjang gelombang masing-masing mineral antara lain: $\mathrm{Na}$ 589,0 nm; K 766,5 nm; Ca 422,7 nm; Mg 285,2 nm; Fe 248,3 nm; Mn 279,5 nm; dan Zn 213,9 nm. Limit deteksi untuk masing-masing mineral antara lain: Na 0,10 ppm; K 0,18 ppm; Ca 1,77 ppm; Mg 0,06 ppm; Fe 0,17 ppm; Mn 0,10 ppm dan Zn 0,10 ppm. Absorbansi sampel diukur pada panjang gelombang dari masing-masing mineral yang terkandung didalam sampel.(Nursanto Iman, 2004)

\section{HASIL DAN PEMBAHASAN}

Minuman rumput laut yang berhasil dibuat disajikan dalam Gambar 1 

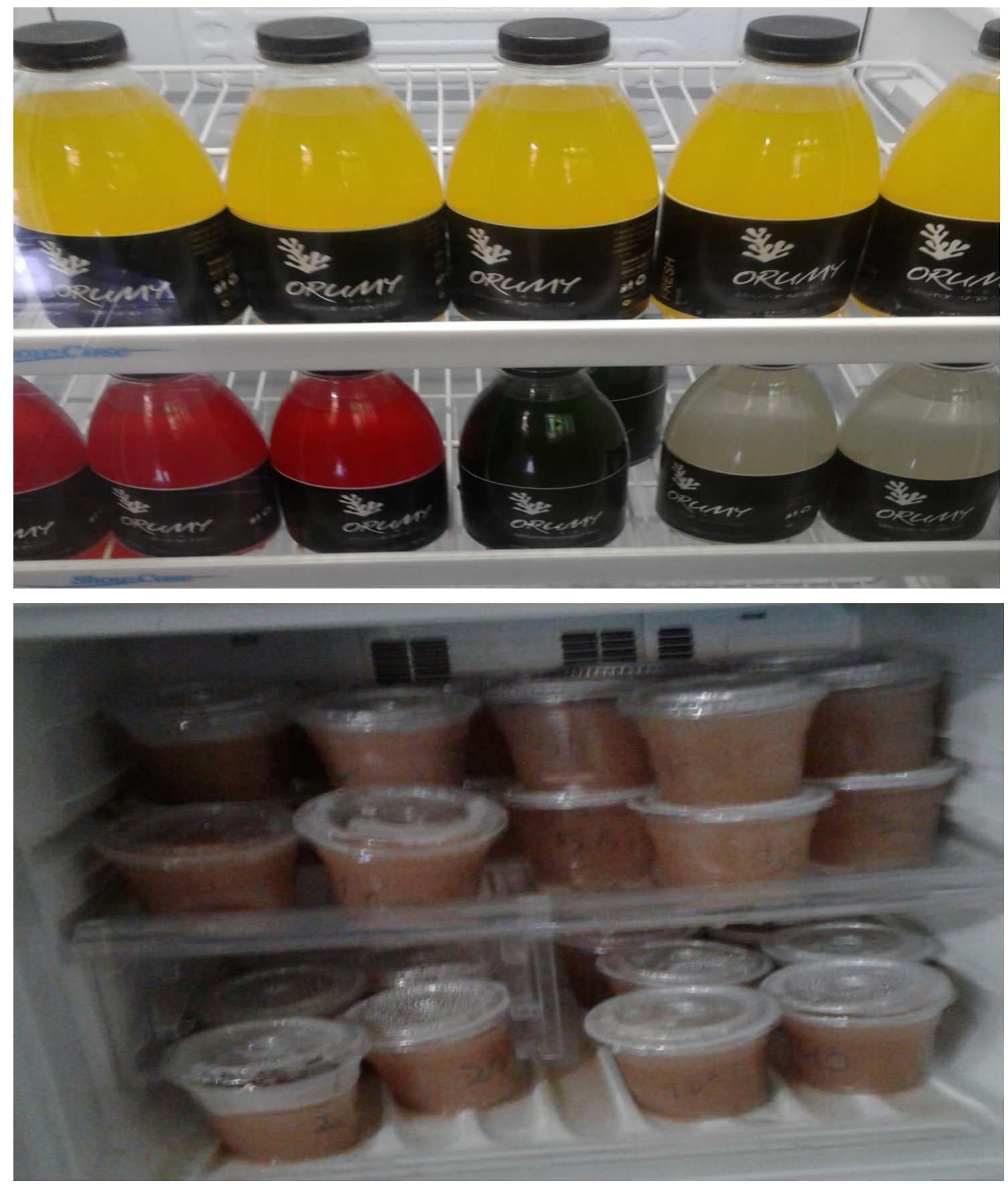

Gambar 1: Minuman Rumput laut

Potensi produksi minuman rumput laut di daerah Dolly cukup besar, sehingga dukungan dari berbagai pihak, termasuk sistem pemerintahan sangat diperlukan guna peningkatan usahanya. Seperti yang telah diketahui, bahwa rumput laut mempunyai nilai nutrisi yang sangat tinggi, yaitu Serat Kasar, Protein serta Karbohidrat. Zat-zat tersebut sangat diperlukan guna menjaga dan mengatur metabolisme tubuh, sehingga sangat baik untuk dikonsumsi. 
Protein, tersusun atas banyak asam amino yang terdiri atas unsur-unsur $\mathrm{O}, \mathrm{C}, \mathrm{N}$ dan $\mathrm{H}$ bahkan ada $\mathrm{P}$ dan $\mathrm{S}$ sehingga merupakan senyawa organik kompleks. Protein sangat diperlukan oleh tubuh yang mana berfungsi sebagai zat pengatur, zat pembangun dan zat pembakar. Protein berfungsi pada proses pembentukan hormon dan enzim yang memegang peranan penting proses metabolisme tubuh. Sebagai zat pembangun protein berperan dalam proses reproduksi, membatu tumbuhnya jaringan baru apabila tubuh terluka dan bahkan dapat mengganti jaringan yang rusak. Di dalam tubuh, protein dapat berperan sebagai sumber energi apabila karbohidrat dan lemak tidak mencukupi pemenuhan sumber energi. Hasil analisa yang telah dilakukan menunjukkan kadar protein yang terdapat pada minuman rumput laut adalah 7,4 gr.(Istiani, A, Suhaimi, \& J., 1986)

Karbohidrat, sebagai senyawa organik yang tersusun atas karbon, oksigen dan hidrogen dengan perbandingan tertentu. Karbohidrat mengandung zat bebas nitrogen dan mengandung serat kasar. Pada umumnya karbohidrat sangat mudah larut dalam air apabila dibandingkan dengan protein atau lemak. Adanya serat kasar dapat membantu proses mengeluarkan kotoran berupa feses dari usus besar. Adapun hasil pemeriksaan yang telah dilakukan, menunjukkan kandungan karbohidrat yang terdapat pada minuman rumput laut adalah $76,1 \mathrm{gr}$.(Istiani et al., 1986)

Lemak, kandungan lemak yang terdapat dalam rumput laut sangat rendah, yaitu kurang dari $1 \%$, dengan demikian rumput laut sangat aman dikonsumsi meskipun dalam jumlah banyak. Rendahnya kandungan lemak merupakan alasan utama mengapa rumput laut berperan sebagai komponen utama bahan makanan diet. Meski demikian dalam kadar tentu keberadaan lemak tetap dibutuhkan oleh tubuh manusia. Secara umum, lemak merupakan komponen organik dengan mudah larut dalam pelarut-pelarut organik namun sebaliknya sangat sulit larut dalam air pada temperatur kamar. Lemak merupakan sumber energi yang dominan dibanding protein dan karbohidrat. Lemak dapat menghasilkan energi $8,9 \mathrm{kkal} / \mathrm{gram}$ adapun protein dan karbohidrat masing-masing tidak lebih 4 $\mathrm{kkal} / \mathrm{gram}$. Sedangakan hasil pengukuran dan perhitungan yang telah dilakukan pada minuman rumput laut menunjukkan kadar lemak yang terkandung di dalamnya adalah sebesar 0,7 gr. (Istiani et al., 1986)

Komponen Mineral, Rumput laut yang dikombinasi dengan beras merah mengandung cukup banyak elemen mineral, bahkan ada 15 asam amino berhasil diidentifikasi; yakni: asam, jumlah besar (makro-elemen) maupun yang glutamat, asam aspartat, glisin, leusin, alanin,, dibutuhkan dalam jumlah kecil (mikro-elemen). valin, serin, isoleusin, treonin, fenilalanin, prolin,, Pada penelitian ini diperoleh rata-rata kadar lisin, arginin, tirosin, sistein, histidin, dan hidroksi, kalsium. Adapun kadar rata-rata fosfor hasil pengukuran menggunakan spektrofotometer UV-Visible adalah sebesar 359 $\mathrm{mg} / 100 \mathrm{~g}$ berat kering. Kadar fosfor pada rumput laut ini termasuk cukup tinggi, sehingga sangat berpotensi sebagai sumber fosfor bagi tubuh.

Besi merupakan mikro-elemen mineral yang berhasil dideteksi. Pengukuran terhadap kadar besi (Fe) pada rumput laut yang digunakan sebagai bahan minuman ini adalah $0,9 \mathrm{mg}$. Kadar besi yang cukup tinggi tersebut dapat digunakan sebagai alternatif pemakaian rumput laut sebagai sumber zat besi dalam bahan makanan. Kadar elemen mineral rumput laut sangat dipengaruhi oleh kondisi lingkungan tumbuhnya.

Vitamin, Hasil pengukuran yang telah dilakukan, diperoleh rata-rata kadar $\beta$-karoten sebesar 489,55 $\mathrm{g} \mathrm{RE} / 100 \mathrm{~g}$ berat kering. Kadar $\beta$-karoten yang terkandung dalam rumput laut ini sangat sesuai apabila difungsikan sebagai sumber vitamin. Beberapa vitamin lain yang juga terdapat di rumput laut adalah Vitamin E 0,2 mg; Vitamin B1 = 0,35 mg; B6 0,4 mg; Vitamin $\mathrm{K} \mathrm{1,3 \mu g;} \mathrm{yang} \mathrm{mana} \mathrm{vitamin-}$ vitamin ini dapat berfungsi anti oksidan guna peremajaan kulit serta mempercepat proses 
penyembuhan. Dengan demikian kandungan protein dalam rumput laut sangat penting untuk membentuk jaringan baru pada kulit sekaligus mencegah penuaan dini.

Kandungan serat, rumput laut mengandung polisakarida dalam jumlah yang cukup banyak, polisakarida merupakan struktur dinding sel yang diekstrak menghasilkan alginat dari rumput laut coklat, karagenan dan agar dari rumput laut merah. Rumput laut juga mengandung polisakarida lainnya terdiri dari laminarin (-1,3-glucan) dari rumput laut coklat dan tepung floridea (amilopektinseperti glukan) dalam rumput laut.(Soekarto, 1981)

\section{KESIMPULAN}

Pengujian kandungan gizi yang terdapat pada produk minuman sari rumput laut setelah dilakukan modifikasi penambahan beras merah diperoleh komposisi sebagai berikut: energi $=353 \mathrm{kkal}$; protein $=7,4 \mathrm{gr}$; lemak $=0,7 \mathrm{gr}$; karbohidrat $=76,1 \mathrm{gr}$; kalsium $=13 \mathrm{mg}$; fosfor $=359 \mathrm{mg}$; zat besi $=4,5 \mathrm{mg}$; vitamin B1 = 0,35 mg; B6 0,4 mg; vitamin E 0,2 mg; vitamin K 1,3 $\mu$; kalsium 19,6 mg; zat besi 0,9 mg; magnesium 83,7 mg; kalium 83,9 mg; sodium 9,9 mg; seng 1,3 mg; tembaga 0,3 mg; mangan 1,9 mg; selenium 19,4 $\mu \mathrm{g}$.

\section{DAFTAR PUSTAKA}

Anggadiredja, J, S. I. dan K. (1996). Potensi dan Manfaat Rumput Laut Dalam Bidang Farmasi. (BPPT). Jakarta.

Azrina, C. (2006). Kajian Rumput Laut Sebagai Sumber serat alternatif untuk minuman berserat. Bogor.

Istiani, S., A, Z., Suhaimi, D., \& J., A. (1986). Manfaat dan Pengolahan Rumput Laut. Jurnal Penelitian.

Kumalasari. (2010). Perbedaan Penambahan Rumput Laut Eucheuma cottonii Pada Mie Basah Terhadap Kekuatan Regangan (Tensile), Kadar Serat kasar (Crude Fiber) dan Daya Terima. Univ. Muhammadiyah Surakarta.

Nursanto Iman. (2004). Pembuatan Minuman Sebagai Usaha Diversifikasi Rumput Laut Eucheuma cottoni. IPB Bogor.

Soekarto. (1981). Penilaian Organoleptik untuk Industri Pangan dan Hasil Pertanian. jakarta: Penerbit Bhratara Karya Aksara.

Sulistyowaty D. (2009). Efek Diet Rumput Laut Eucheuma sp. Terhadap Glukosa Darah Tikus Wistar Yang Disuntik Aloksan. Semarang. 